\title{
Putting Theory Into Practice: Incorporating a Community Engagement Model Into Online Pre-Professional Courses in Legal Studies and Human Resources Management
}

\author{
Antoinette France-Harris, Christie Burton, and Mara Mooney \\ Clayton State University
}

\begin{abstract}
Scholars widely agree that community-engaged learning can significantly improve the learning experience for students while simultaneously having a positive impact on the community. This paper explores student perceptions in online pre-professional undergraduate courses in the legal studies and human resources management fields in which community-engaged learning projects were utilized. Students were paired with community members in instructor-focused activities linked to their academic curricula. Using reflective discussions, a survey, and focus groups, the instructors attempted to gather important data related to student perceptions of the community-engaged learning experience that builds upon prior research. While specific themes emerged in each course, the most significant findings common to both groups were the following: (1) students recognized the powerful impact of their profession, (2) students realized the increasing importance of soft skills to their success, and (3) students appreciated the growth in their own personal attitudes and professional skills. The student perceptions from these classes should lead to a deeper understanding of the benefits and challenges of community-engaged online classrooms and give guidance for developing future projects.
\end{abstract}

Keywords: community engagement; service learning; experiential learning; student perceptions; legal studies; paralegal studies; human resources; human resources management

France-Harris, A., Burton, C., \& Mooney, M. (2019). Putting theory into practice: Incorporating a community engagement model into online pre-professional courses in legal studies and human resources management. Online Learning, 23(2), 21-39. doi:10.24059/olj.v23i2.1448

\section{Putting Theory Into Practice: Incorporating a Community Engagement Model Into Online Pre-Professional Courses in Legal Studies and Human Resources Management}

Student enrollment in online courses continues in an upward trend, with over six million learners, or over $30 \%$ of all undergraduate students, taking at least one distance education course during their studies (Seaman, Allen, \& Seaman, 2018). As institutions pursue online formats to attract more students and increase capacity, instructors are encouraged to increasingly enhance their online classrooms but may find it daunting to incorporate certain engagement strategies, such as community engagement activities. While there is a growing body of research related to community engagement health care and science-related fields in online education, community engagement has not been adopted commonly in online formats or widely across most disciplines. We took on the challenge of incorporating community engagement into their online courses and 
will share data that enhances the body of research by showing that community-engaged learning facilitates greater student-student, student-content, and student-instructor engagement in online courses in the disciplines of business and law. This project will therefore assist other instructors in their pursuit to transform their online courses with a community engagement strategy.

Community engagement has a long history as a pedagogical tool that combines classroom learning goals with targeted community service projects to enrich the academic experience and strengthen civic awareness (Brail, 2013). Community-engaged learning expands the classroom into a social context far broader than four walls or assigned readings and can be successfully utilized in in-person and online classes (Carnegie Foundation, 2008; Sheafer, 2014). In shifting focus from lecture or other teacher-centric instructional activities, students in community-engaged classes work with community partners to put their theoretical learning to practical use (BeharHorenstein et al., 2016). Knowledge is absorbed in a more active environment and translates into better retention of the material. In a study by Brail (2016), after two weeks, students remembered $20 \%$ of what was said in a lecture versus $90 \%$ of what the students actively put to use on the topic. Connecting with course material on a deeper level can also lead to higher retention and graduation rates (Quaye \& Harper, 2015). In its ideal form, community-engaged learning promotes partnerships between a university and the outside world, forging relationships that are mutually beneficial and that produce graduates with a strong sense of social awareness (Bringle, Hatcher, \& Jones, 2011; Sapp \& Crabtree, 2002).

Because of these perceived values of community-engaged learning, we decided to gather data from the student perspective in their online community engagement classes. In this paper, we begin with a discussion of the existing body of research in this area. Then, we describe the specific community engagement projects for each class and the methodology used to gather data. Next, we analyze the data and outline the results and limitations of the study. We end with conclusions that can be drawn from our study and lessons learned.

\section{Review of Literature}

We were particularly interested in exploring students' perceptions of a communityengaged learning experience and in ascertaining the rewards and challenges associated with this pedagogical tool, particularly when utilized in an online setting. For example, it has been found that community-engaged learning can enhance students' understanding and interest in the subject matter being studied and may result in enhanced participation in the classroom and improved social and economic benefits in the community (McGorry, 2012). Additionally, as higher education offers more courses online (McNiff \& Aicher, 2017), the incorporation of communityengaged learning into online courses presents opportunities for higher education to integrate community engagement into all levels of the curriculum. And, while few students are currently exposed to it in their online coursework, it has been found that community-engaged learning must become part of the online learning experience to remain relevant and transformative (Waldner, McGorry, \& Widener, 2012). Other potential benefits of community-engaged learning are an increased pre-professional identity developed in students and benefits to the larger community (Jackson, 2016a). The literature also reveals the importance of assessing student perceptions and the utility of incorporating these findings into future studies. Finally, as will be discussed more fully below, the literature reveals challenges across stakeholders associated with incorporating community engagement into the classroom. 
As noted by Chickering and Reiser (1993), learning is "not a spectator sport," and a traditional teacher-centered atmosphere often fails to bridge the gap between subject matter and a student's meaningful construction of that knowledge, skill, and value (Moore, Boyd, \& Dooley, 2010). Further, as students in today's college classrooms come from highly diverse backgrounds, faculty and administrators should seek ways to actively engage students in meaningful activities linked to the larger cultural landscape around them (Pelco, Ball, \& Lockerman, 2014). Kuh, Kinzie, Buckley, Bridges, and Hayek (2007) argued that meaningful student engagement encompasses "educationally purposeful activities" and the level of support and engagement opportunities provided by an institution to induce students to participate in these activities. Institutions of higher education are increasingly concerned with program learning outcomes and the extent to which courses meet these stated objectives through activities and student performance. Community engagement has been found to be a predictor of students' increased attainment of learning outcomes for a program of study (Prentice \& Robinson, 2010). Assignments that immerse online students in the larger community also give students practice in grappling with the complexity of their personal values despite not occurring in a traditional classroom (Bourelle, 2014; Kelly \& Miller, 2008; Nielsen, 2016). Other potential benefits include the development of stronger democratic values and civic responsibility, critical thinking growth, and an enrichment of the scholarship and creative activities of faculty (Feen-Calligan \& Matthews, 2016; Miles, Reed, Brown, \& Allen, 2009). Although research has revealed that community engagement activities are associated with positive student perceptions, additional research is needed to determine the factors that account for this increase (Furze, Black, Peck, \& Jensen, 2011; Hoppes, Bender, \& DeGrace, 2003).

As members of the faculty have become more aware of the potential pedagogical and social benefits from community-engaged learning, a movement to incorporate these types of experiences into online classrooms is growing (Hervani, Helms, Rutti, LaBonte, \& Sarkarat, 2015). Particularly in Web-based classrooms, being involved in the larger community as part of an online course may also help to alleviate learner concerns about a perceived lack of community that can sometimes exist in an online setting (Bernier \& Cheryl, 2016; Sadera, Robertson, Song, \& Midon, 2009; Song, Singleton, Hill, \& Koh, 2004). Community engagement can facilitate intraclass interaction and increase online social presence as students share their experiences with the class while working on projects with community partners (Rovai, 2002). Studies have shown that in online classes, this type of civic engagement will create a sense of community and purpose that is critical to student success (Sadera et al., 2009). Butchey's (2016) AT-EASE model for an online community-engaged class is broken into six Cs: connections, coordination, conversations, confidence, choices, and competence. These six stages begin when a learner is first acquainted with a subject matter, and they extend to those steps during which the student works to coordinate the community-engaged learning activity through conversations with other students, the faculty, and the community partner. As students begin to apply their knowledge and to solve community problems while working directly with clients, they develop the confidence to ask probing questions that ultimately facilitate decision-making and their capacity to recommended solutions. This type of embedded community-engaged learning reinforces the curriculum and promotes a deeper level of competence and empowerment in students while translating into a more robust experience for the community partner.

Additionally, the experiential skills and perceptions developed by students in a community-engaged model can contribute to the emergence of a student's pre-professional identity, which is an early connection to an intended profession that can bolster a student's 
development and success (Jackson, 2016a). A second study by Jackson (2016b) found that preprofessional identity is an underexplored concept that can influence one's academic success, wellbeing, and productivity in the classroom and beyond. Further, she found that having students appraise and reflect on their experiences in a community engagement project is critical for each student to reach a deeper understanding, to "question and make sense" for themselves, of what they have observed and learned (Jackson, 2016b). A 2017 study by Zhao and Zhang explored the development of pre-professional identity in teacher education students. Utilizing a mixed methods research approach that included student reflections, the study indicated that fieldwork in a practice-specific setting is linked to students developing their belief in the value of the teaching profession and promoting the students' professional commitment. In a study of pre-professional wildlife management students, Stevenson and Peterson (2015) found that students who participated in career-related community-engaged learning were exposed to soft skills that broadened their perspectives and opened their eyes to a variety of employment options. As students actively participate in real-world activities, these experiences can translate into some of the most meaningful and impactful moments, lasting long after a diploma has been awarded and bridging gaps between academia and the employment sector (Barker, 2004; Felton \& Clayton, 2011; Smith, Smith, Taylor-Smith, \& Fotheringham, 2017).

A common theme in much of the literature is the importance of assessing students' perceptions of their community engagement experience, and several methods, such as interviews, focus groups, journal assignment analysis, and analysis of videotaped interactions, exist to assess students' social learning and to identify areas for improvement (Brown, 2001; Cooks \& Scharrer, 2006; Schindler, 2014; Sheafer, 2014). Jenkins and Sheehey (2012) argued that student reflection pieces seem to be the most frequently used form of assessment. Student participation in community engagement projects combined with structured reflection has been found to provide meaningful insight into the participants' personal beliefs and self-awareness (Furze, Black, Peck, \& Jensen, 2011). The incorporation of student reflection into a course also dovetails nicely with the use of nonlinear paths of learning (Bourelle, 2014). In nonlinear environments, particularly those online platforms that engage in community projects, students gain new perspectives and solve problems more adequately because learning is integrated and not separated into discreet, linear "boxes," which mimics more closely the "unscripted nature" of the real world (Dailey-Hebert \& Donnelli, 2010).

Analysis of embedded assignments, such as written reflections and surveys, suggests that community-engaged learning facilitates growth in personal attitudes and professional skills considered important to preparation for the work world (Feen-Calligan \& Matthews, 2016; Moore, Boyd, \& Dooley, 2010). According to Murray, Plante, Cox, and Owens (2015), more studies are needed that focus on the effectiveness of community-engaged learning projects, with a special focus on how individual students are impacted by the experience. By soliciting student feedback along the way, this information can help shape and reshape the projects. Additionally, the implementation of a carefully considered community-engaged learning project that includes reflection and surveys in online environments serves as a method to improve teaching, motivate student writing, promote teamwork, and create virtual collaborative presentations (Helms, Rutti, Hervani, LaBonte, \& Sarkarat, 2015). A study by Lehman and Conceicao (2010) found that self-reflection is critical to success in online learning because it enables students to transcend the online environment by becoming intimate with the project itself and the individuals involved. 
While scholars and practitioners largely agree on the positive attributes of community engagement, several challenges exist, particularly in the online context. For example, since many students ostensibly enroll in online classes because of the flexibility afforded, when a professor requires time working in the community, this flexibility may be limited and the class less appealing to students with busy outside work and home lives (Bossaller, 2016; Song, Singleton, Hill, \& Koh, 2004). Also, when students work collaboratively, the variable of group composition can undercut the experience for some students if not all group members are contributing in a meaningful way.

Despite these challenges, community engagement seems to be worth the undertaking, particularly for students studying in pre-professional fields who have the unique advantage of receiving feedback from clients, customers, and/or community partners on the efficacy of the student's efforts within their anticipated field. This feedback is a valuable tool as students reflect inward and evaluate their degree of fit within a profession. These experiences will also help students to more realistically calibrate their expectations of a profession and identify any gaps in their qualifications and their preparedness to enter the field. In reviewing the literature, we found consistency in the findings that community-engaged learning promotes a deeper understanding of course objectives, fosters pre-professional identity, and bolsters community relations. However, in answering the call for more research to assess how students are impacted by communityengaged learning, we sought to explore students' perceptions of their community engagement experience, to draw conclusions about what worked well and what was not as successful, and to replicate the courses in future semesters using these lessons learned. The main questions we sought to answer with our research were the following:

- Does community-engaged learning in online paraprofessional classes create an environment for greater student-student, student-content, and student-instructor engagement?

- Is community-engaged learning an effective pedagogical tool that can enhance the quality of online courses from a student perspective?

\section{Methods}

This project was part of a university-wide initiative to support and facilitate community engagement and was one of a small contingent that adopted community engagement in an online setting (six out of 51 courses). To support the university-wide initiative and to foster student involvement, instructors in legal studies and human resources management each redeveloped one of their online courses to incorporate a community engagement project. Students in the legal studies course prepared powers of attorney, advance directives for health care, and wills for members of a Habitat for Humanity community under the direction of their instructor, a licensed attorney. The human resources management students evaluated the effectiveness of the training and hiring functions of local organizations. We will present lessons learned and best practices, with special emphasis on students' reflections, surveys, and interviews.

The legal studies and human resources management disciplines are competencybased, and students benefit when they can practice the skills they learn in real-world, low-stakes environments. For this reason, a community engagement assignment was well-suited for these courses and took advantage of what Gruenwald (2005) and Lysne et al. (2013) noted as critical 
for 21 st-century students - that is, understanding the notion of place. Rather than learning being relegated to inside the four walls of an institution, learning can happen everywhere, and different places teach us about how the world works and how our lives fit into the spaces we occupy.

\section{Data Collection}

In this qualitative study, students participated in an assigned community engagement project that they could complete either individually or in a group. Approval from the university's Institutional Review Board was received, and students were invited to include their project data in a study titled Community Engagement in Online Classes. A total of 41 students consented to participate ( 23 out of 26 in the legal studies course and 18 out of 22 in the human resources management course). The respondents to the legal studies survey were $74 \%$ minority, $78 \%$ female, and $48 \%$ part-time. Data from the human resources management class came from students who were $82 \%$ minority, $67 \%$ female, and $84 \%$ part-time. In both courses, student reflections were collected using the Desire2Learn (D2L) learning management system.

Reflection questions were selected as a data collection method because of the advantages they offer. They (1) are student-centered measures that allow participants to complete them at times that best fit their progress and schedules and (2) allow students opportunity to revisit questions, spending time with the questions that were particularly meaningful or thoughtprovoking. Both factors aided in the construction of knowledge and enable students to recognize their own growth while providing information to the researchers about students' perceptions of their community engagement experiences.

The instructors developed reflection questions that students would find straightforward and accessible, so that students would more easily be able to contemplate and reveal their experiences as they engaged in the project. Posing simple questions is a good way to "promote participants" self-disclosure through the creation of a permissive environment" (Marshall \& Rossman, p. 84, 1995). The legal studies reflective questions are listed on Table 1, while Table 2 outlines those from the human resources management course.

In addition to the reflection questions about the nature of student experiences, each instructor wanted to evaluate the process to identify areas for improvement that would help with designing future community engagement courses. Because of its efficiency in both collection and analysis, the legal studies instructor created and administered a 15-item survey that is shown in Table 3. Alternatively, the human resource management instructor assigned a focus group interview in her class (see Table 2) with the goal of building upon the information already collected through self-reflections. Students were asked to participate in one of three virtual WebEx meetings after final projects were submitted.

Table 1.

Legal Studies Questions

After watching the video in this folder which includes information about the
value of service-learning projects to students, faculty, schools and the
community and reading the article regarding the importance of pro bono
legal work for attorneys and paralegals, please share your thoughts,
including details about any previous experience with volunteer or pro bono
work, how you feel about this aspect of the course, and what you expect to
gain from the experience.




\begin{tabular}{|c|c|}
\hline \multirow[t]{2}{*}{ Reflection 2} & $\begin{array}{l}\text { How were the concepts you are currently learning about in class reflected in } \\
\text { your recent client visit? What are the similarities and differences between } \\
\text { the concepts and reality? }\end{array}$ \\
\hline & $\begin{array}{l}\text { What useful skills did you discover during your client meeting? How might } \\
\text { you apply these newly discovered skills to other situations? Did you use a } \\
\text { skill that you didn't think you would need or use? Why? }\end{array}$ \\
\hline \multirow[t]{4}{*}{ Reflection 3} & $\begin{array}{l}\text { Describe a significant event that occurred as a part of the service- } \\
\text { learning experience this semester. }\end{array}$ \\
\hline & Why was this significant to you? \\
\hline & $\begin{array}{l}\text { What underlying issues (societal, interpersonal, professional) surfaced } \\
\text { because of this experience? }\end{array}$ \\
\hline & How will this incident influence your future behavior? \\
\hline
\end{tabular}

Table 2.

Human Resources Management Questions

\begin{tabular}{ll}
\hline Reflection 1 & How were the concepts you are currently learning about in class reflected in \\
your visit to your organization? & What are the similarities and differences between the concepts and reality? \\
& What useful skills did you discover during your client meeting? How might \\
you apply these newly discovered skills to other situations? & Did you use a skill that you didn't think you would need or use? Why? \\
Reflection 2 & What was the best thing that happened and what was the most challenging in \\
Focus group & What did you enjoy about this project? \\
interview questions & What surprises did you have during the process of working on this project? \\
& $\begin{array}{l}\text { What tips or advice would you give to other students who will work on this } \\
\text { project, either in the preparation or execution of the phase? } \\
\text { What suggestions do you have to improve this experience for future } \\
\text { students? }\end{array}$
\end{tabular}

Legal studies. The legal studies project was offered in the instructor's online Wills, Trusts, and Probate Law class. Students worked in groups to draft estate planning documents for lowincome individuals in the campus's surrounding community. Students were aware of the community engagement component of the class before they registered, and the syllabus clearly outlined the semester-long project and objectives related to a community-engaged learning course. Initially, the instructor explained the importance of pro bono work in the legal field and offered students the opportunity to reflect on service and their expectations of the experience. After a month of instruction, the instructor and her students met with their clients for the first time. She conducted an information session, distributed literature, and advised the clients of the importance of estate planning. Then, her students conducted client interviews utilizing a questionnaire. Thereafter, using an online discussion board, the instructor had the students reflect on the client 
meeting. Subsequently, the students began drafting the necessary documents and submitting them to the instructor for her review. After they finalized the documents, the instructor and each group had a conference call with each client to review the details prior to the execution of the documents. At the second and final meeting with the clients, the students and instructor explained the documents again and had them signed and notarized. Upon completion of the project, the instructor provided the final opportunity for students to reflect on their community engagement experience on another online discussion board.

In addition to the discussion boards referenced above, the instructor created and conducted an anonymous student survey at the end of the semester. She asked the students 15 questions to gather formal data regarding their perceptions of the project's effectiveness. Twenty-three of the 26 students enrolled in that class $(88.5 \%)$ responded to the survey. The questions and student responses, including the scale of possible responses, are recorded on Table 3.

\section{Table 3.}

\section{Survey of Student Perceptions in Legal Studies Course}

\section{Questions}

1. Would you take another community engagement class if offered the opportunity?

2. Do you believe that the community engagement component of this online class added positively to the course?

3. Did you enjoy the community engagement component of this online course?

4. Has the community engagement component of this online course encouraged you to do more pro bono work in the future?

5. Have you taken online courses before or during this semester?

6. Compared to other online courses you have taken, the quality of interaction with other students in this class:

7. Compared to other online courses you have taken, the amount of interaction with other students in this class:

8. Compared to other online courses you have taken, the amount of interaction with the instructor in this class:

9. Compared to other online courses you have taken, the quality of interaction with the instructor in this class:

10. Compared to other online courses you have taken, the quantity of your learning experience in this class:

11. Compared to other online courses you have taken, the quality of your learning experience in this class:

12. Compared to other online courses you have taken, my motivation to participate in class activities in this class:

\begin{tabular}{|c|c|}
\hline \multicolumn{2}{|c|}{ Responses } \\
\hline $21=$ Yes & $2=\mathrm{No}_{\mathrm{o}}$ \\
\hline $23=$ Yes & $0=\mathrm{No}$ \\
\hline $20=$ Yes & $3=\mathrm{No}$ \\
\hline $22=$ Yes & $1=\mathrm{No}$ \\
\hline $22=$ Yes & $1=\mathrm{No}$ \\
\hline \multicolumn{2}{|c|}{$15=$ Increased } \\
\hline \multicolumn{2}{|c|}{$6=$ Stayed the same } \\
\hline \multicolumn{2}{|c|}{$2=$ Decreased } \\
\hline \multicolumn{2}{|c|}{$17=$ Increased } \\
\hline \multicolumn{2}{|c|}{$4=$ Stayed the same } \\
\hline \multicolumn{2}{|c|}{$1=$ Decreased } \\
\hline \multicolumn{2}{|c|}{$17=$ Increased } \\
\hline \multicolumn{2}{|c|}{$5=$ Stayed the same } \\
\hline \multicolumn{2}{|c|}{$1=$ Decreased } \\
\hline \multicolumn{2}{|c|}{$16=$ Increased } \\
\hline \multicolumn{2}{|c|}{$6=$ Stayed the same } \\
\hline \multicolumn{2}{|c|}{$1=$ Decreased } \\
\hline \multicolumn{2}{|c|}{$15=$ Increased } \\
\hline \multicolumn{2}{|c|}{$7=$ Stayed the same } \\
\hline \multicolumn{2}{|c|}{$1=$ Decreased } \\
\hline \multicolumn{2}{|c|}{$14=$ Increased } \\
\hline \multicolumn{2}{|c|}{$7=$ Stayed the same } \\
\hline \multicolumn{2}{|c|}{$1=$ Decreased } \\
\hline \multicolumn{2}{|c|}{$11=$ Increased } \\
\hline \multicolumn{2}{|c|}{$\begin{array}{l}11=\text { Stayed the same } \\
1=\text { Decreased }\end{array}$} \\
\hline
\end{tabular}


Table 3. (Cont.)

Survey of Student Perceptions in Legal Studies Course

13. Do you believe that the community engagement project helped to foster the instructor-to-student interaction in this class?

14. Do you believe that the community engagement project helped to foster the student-to-student interaction in this class?

$12=$ Definitely yes

$10=$ Probably yes

$0=$ Might or might not

$0=$ Probably not

$0=$ Definitely not

$9=$ Definitely yes

$12=$ Probably yes

$2=$ Might or might not

$0=$ Probably not

$0=$ Definitely Not

15. Do you believe that the community engagement project strengthened your grasp of the course material?

$15=$ Definitely yes

$5=$ Probably yes

$1=$ Might or might not

$2=$ Probably not

$0=$ Definitely not

Note. Number of responses $(n=23)$

Human resources management. The other community engagement project was assigned to 22 students in an online human resources management course. Using concepts learned in the course, students acted as consultants of training or personnel selection and collected information on the mission, goals, programs, and organizational structure in either a local business or nonprofit organization. Working individually or in groups, they provided analysis and recommendations that highlighted areas of exemplary behavior and opportunities for improvement. Students met with their client organizations as needed and delivered a final report of their findings at the conclusion. At various stages in the project, students submitted an agency selection form, completed two discussion posts that prompted personal reflection on the project, and participated in an after-action focus group interview. In the six-week human resources management project, Reflection 1 was to be completed sometime during Weeks 1-3, after initial contact with the client. Reflection 2 was to be completed sometime during Weeks 4-6, when students would have had additional contact with their clients and more time to process their experiences.

An additional data collection measure, an after-action review focus group, was included in the human resources management course to glean lessons learned and provide closure for the project. Students were asked to participate in one of three virtual WebEx meetings after final projects were submitted. Interaction in a focus group enables participants to further develop and refine their views, enhances data quality, and, in the case of computermediated forums (such as discussion boards), has the added benefit of reducing anxiety since participants and moderator are physically separated (Patton, 2002).

\section{Data Analysis}

This study used content analysis to evaluate students' perceptions and descriptive statistics for the survey. Analysis was performed to understand how students perceived their experiences in each course, and data was then evaluated to see how the two courses compared.

The first step in our analysis was to read all the responses to get an overall sense of the general ideas and tone that participants were communicating (Tesch, 1990). During this 
process, we reflected on the participants' comments to understand their meaning, making notes regarding the direction the responses seemed to be headed to sort through the raw data. It was essential that we continually referred to the main purpose of our research, which was to explore students' perceptions of their community engagement experience to uncover the essential meaning of the students' comments. Frequently referring to our focus grounded our analysis so that the responses were continually viewed as connected rather than disparate statements, guarding against the danger of being overwhelmed with so many individual comments (Miles \& Huberman, 1994).

The second step in our analysis was to organize the data by finding common themes or categories among all the students' responses. Boyatzis (1998) calls these data driven codes because they consist of the words and phrases the researcher finds compelling, rather than labels created a priori from theory or prior research. We read and reread each of the comments along with their category heading several times to determine whether students' comments were correctly placed, and then we analyzed each response separately to determine its interconnection with other themes. At this stage, we looked for saturation of categories - that is, the degree to which new comments minimally altered the dimensions of the category, as well as the regularity with which similar meanings were expressed. Lincoln and Guba (1985) note that this process helps to ensure that the breadth and depth of participants' intended meanings are accurately represented. Themes related to student perceptions of the community-engaged learning experience emerged in both classes; they are more fully described below.

\section{Results}

In keeping with the purpose of exploring students' perception of their community engagement learning experience, the following themes emerged among legal studies students: (1) appreciation for the legal profession and philanthropic opportunities therein, (2) development of professional identity, (3) dissatisfaction with group processes, and (4) development of personal advocacy.

Legal profession and philanthropy. In their reflection assignments, students expressed great excitement about offering a much-needed service to the community. For many, it was the first time they had interacted with a real-life client or participated in any type of community service. They confided that this experience encouraged them to continue to provide future pro bono legal assistance to those in need. It also excited them about their future careers in the legal field. The instructor encouraged her students to include this invaluable experience on their résumés and to speak about it in interviews with potential legal employers.

Professional identity. The students commented that in most of their other legal studies classes, they had used only hypothetical fact patterns to illustrate legal concepts they had learned; however, the community engagement project afforded them the opportunity to do valuable work outside of the classroom to assist actual clients in immediate need. Students expressed that they were more invested in the project because the outcome was of utmost importance to their client. Moreover, the students employed many of the legal ethics they had been taught in previous classes as they worked towards their goal, including confidentiality, competent representation, and due diligence.

Group processes. Some students indicated that they were not fond of working in groups. As is typical, there were reports of students within the group who did not do their fair share. The remaining group members would then have to pick up the slack for the irresponsible 
student(s) to complete the project successfully. In addition, there were personality conflicts in a couple of groups. Sometimes, there were group members who did not get along because they had different learning styles, work ethics, or ideas about how and when a task should be completed. The instructor tried to encourage group members to resolve their personal differences internally, if possible, and to remember the primary focus of addressing their clients' needs. Finally, some students expressed frustration related to poor communication among group members or with their clients. Because it was an online class and students had various work and personal schedules, it was often difficult to coordinate times for conference calls or meetings that were convenient for all group members and their client. Despite these issues, overall, in their final reflections, the students indicated that the community engagement component of the class was something they treasured. The students appreciated even the negative project experiences, as they were also able to glean valuable lessons about themselves and teamwork from those experiences.

Personal advocacy. Finally, in their reflections, many students pointed out that the project made them more self-aware with regard to issues surrounding death and dying and the importance of estate planning for their families. Students learned of the various reasons people avoid estate planning in the textbook and directly from their clients. Common reasons include procrastination, lack of money, and lack of knowledge about the necessity of estate planning. After completing the project, some students stated that they would soon prepare their own estate planning documents. Others mentioned that they were now educating and encouraging family members to have them prepared. Still others shared stories about turmoil that had resulted after family members had died without these documents in place, and they cautioned classmates against this lack of preparation.

These reflection observations were confirmed in the results of the anonymous end-ofsemester survey, which is fully outlined in Table 3 . All the respondents indicated that the project added positively to the course. An overwhelming majority (96\%) of the respondents stated that it encouraged them to engage in future service to the community. Finally, the survey confirmed that compared to other online classes they have taken, students believed that the community-engaged learning class offered greater student-instructor, student-student, and student-content engagement.

\section{Human Resources Management}

Similarly, in analyzing students' reflection comments in the human resources management course, several themes emerged. For Reflection 1, the comments fell into two topics related to (1) reinforced course concepts and (2) skill development in professional practice. For Reflection 2, the comments sorted between (1) encountering positive experiences and (2) encountering challenging experiences. These themes and comments are presented below, and a selection of especially poignant student comments relative to these concepts appears in Table 4. 
Table 4.

Select Student Reflection Comments From Human Resources Management Course

Professional "I have to be careful what I ask. The founder of the organization didn't answer my practice questions in full, so I had to find another way to get the information I needed."

"Non-profits tend to be a lot more reserved when sharing information about their organizations. The level of privacy and unwillingness to allow outside guidance makes me a little skeptical."

"I had a list of questions prepared for my interview but when I got there it wasn't that easy. I had to go back the next day to follow up."

"The most useful skill I found was listening and analyzing. I reviewed my notes and then decided how to proceed."

Positive "The best thing is that I have been interested in this organization since I was a little girl. experiences It was heart-warming to see what they offer the community."

"The best thing was realizing that I could transition from military to corporate. I have never worked in in the corporate world, and it felt good to look into a company to see where my degree applies and how I can make a difference."

"My project gave the business owner a chance to do a real introspective to see where it needed to improve."

"The best part was that it gave me the opportunity to share valuable knowledge with an organization to whom it would be beneficial. The organization does not have a formal HR staff; therefore, they can benefit from the tools and resources provided in my presentation. It was rewarding to share the fruits of my education with others."

"The best thing that came from this project was a job offer in the HR department. After completing the project, I submitted it to the director of operations, and they loved it. They will be using my PPT for training. It was challenging to determine the best way to give my suggestions, and it turns out that something as simple as a visual representation for upper-level management enabled them to be more open to other thoughts and opinions. The company made me feel like a partner."

Challenging "My biggest challenge was confidence. Although I had the resources (books, Internet) experiences and the owner was willing to help me, I was constantly concerned that I was not knowledgeable enough to complete it satisfactorily. I had a plan but was unsure if it was appropriate. I felt the owner had high expectations on the proposal and the results might not be in line with what she really needed."

"My most challenging issue was communication-at times I found myself stumbling over my words and speaking lower than I normally do."

"Working within the schedules of the client made communicating difficult."

"It's very challenging to find a company that wants to work with you."

"Narrowing the scope of the assignment into a usable form was hard. There was lots of information and I had to figure out what was important and how to put it into the right format, filter it down and apply it to the topics from the course." 
Course concepts. Students learned that organizations vary in their use and adherence to established human resources standards and practices. Students were surprised that their community partner either did not follow any of these standards or that they complied with most of them. Many of the students found that the organization selected the practices that worked for it and then adapted them according to its needs. This helped students discover that classroom concepts will provide a foundation and starting point, but their professional judgment will determine how best to apply that knowledge in a real-world environment.

In addition, students learned that use of human resources standards varied depending on the organization's size, sector, and purpose. Students found that larger, for-profit organizations often followed established practices because they could afford the necessary staff and training. Smaller enterprises were more constrained by their limitations and required the owner or manager to wear multiple hats. An exception to this was nonprofit organizations with a governing board that provided direction and funding.

Professional practice. Students learned that communication skills, emotional intelligence, and resourcefulness are competencies that improve with practice and are complements to their technical knowledge that they will bring to their jobs. Students discussed difficulties obtaining the information needed during an interview. Common reasons were (1) the contact was uncooperative, (2) the student was not asking the right questions, or (3) there were restrictions placed on what would be divulged. This required students to try different ways of building trust, listen for what was not said, rephrase questions, and manage their emotions and expectations.

Positive experiences. The most frequent positive perceptions cited were (1) students enjoyed working with people or organizations they admired, (2) students were treated as knowledgeable professionals, and (3) students realized that they fulfilled a real need.

Because students in the human resources management course could choose their community partner, many of them chose organizations that they were either familiar with or interested in. When students chose their church or a social service agency, they commented that it was rewarding to interact with the leaders who made a positive impact. In some cases, students worked with small proprietors with whom they shared a mutual connection, and often these enterprises were short on staff and resources. These client contacts saw the value in what our students offered and treated them with respect and professional courtesy. Because the organization often had limited access to human resources training, the students could identify gaps in their operations that the client had not seen before, and this gave students great satisfaction.

Challenging experiences. The most frequent challenging perceptions cited were (1) students found it hard to gain access to an organization, and then it was slow-going once inside; (2) students feared that they were personally inadequate; and (3) students struggled with time pressures. Almost all students stated that they either were worried about finding a community partner or had actual trouble finding one. Some of the comments reflected that they felt anxiety beforehand when trying to locate partners while others had to employ the help of friends to get access, and still others tried a couple of different organizations before finding the right one.

Many students expressed low confidence in their knowledge and ability to evaluate and present the information they collected, both to the organization and to the instructor. The realworld context added another layer of accountability, and most students did not possess prior experience interacting with upper management to draw upon. Dealing with the time constraints of 
their contact and their personal limitations also made some students feel as if they were often behind schedule. These themes were important discoveries because students learned that resilience in a difficult work situation and persistence produce progress and success.

The instructor planned to revisit students' perceptions and obtain suggestions for improving the assignment by holding focus group interviews at the end of the project. Accordingly, the questions prepared for the interview were simple starting points to prompt free-flowing discussion. Although several time slots were offered, only three students signed up, and there was not enough participation to hold the group interviews, unfortunately.

\section{Discussion}

In comparing students' perceptions in the legal studies and human resources management courses, there were several clear themes that consistently emerged. First, students were pleasantly surprised about the power of their professions. Although students in each course delivered distinctly different services to their respective clients, those differences did not obscure the positive human impact that was achieved. While students learn the nuts and bolts of their profession in the classroom, the human side can be difficult to replicate. However, this deficiency was resolved in the community engagement project. At the project's end, when students saw that their clients' estates were legally protected and that small businesses had solved their internal dysfunctions, students realized that their work can change people's lives for the better. Smith et al. (2017) noted that this kind of professional identity making greatly improves student employability and bridges the gaps between academic and the employment sector.

Secondly, students in both groups learned that good communication and interpersonal skills are essential, and increasingly important, ingredients of success. At different times during the project, legal studies students expressed frustration with some of their group members, as did the human resources management students with some of their clients. Students often think that the difficulties they experience when working with others on school projects will magically disappear once they graduate and get in the real world, not yet realizing that frustrations with colleagues can be a catalyst in problem-solving when common goals are shared. The community engagement project gave students a realistic preview of how human relations function, consistent with Stevenson and Peterson's (2015) findings on the importance of identifying appropriate workplace soft skills.

Lastly, students noted their personal growth while working on their projects. Some students in both classes said they felt inadequate to advise their clients since they were still students. However, this feeling began to change when their clients were impressed with their work or implemented their suggestions. Moreover, when the legal studies students received appreciation from their clients for help with a sensitive matter, they learned that they could navigate the emotional side of the process and were further encouraged to tackle legal planning for themselves and family members who expressed reluctance. Past research has shown that this kind of growth in personal attitudes and professional skills is important preparation for the work world (Feen-Calligan \& Matthews, 2016; Moore, Boyd, \& Dooley, 2010).

\section{Limitations}

If we were to run a subsequent model of this study, we would try to secure a larger data pool (although having students in two different disciplines served as a good intracomparison for 
the study at hand). Perhaps, we would also survey the community partners to assess their experiences, but since we had a student-centric focus we did not survey outside participants. Similarly, further research might focus on the lessons learned for instructors and suggestions for effective community engagement course design. For example, although the human resources management focus group interviews were unsuccessful, a lesson learned from its failure is that adding an additional requirement at the end of an already stressful and time-consuming project was too taxing and perhaps better placed earlier in the project timeline. Students may also have seen this group activity as incongruent with their expectation of maximum flexibility in an online course and chose to opt out. Finally, as noted by Sheafer (2014), student reflections alone may not be the most reliable measure. Using student evaluations as source data is limiting, since self-reporting is subjective and through the lens of one audience. However, in the Sheafer study, as in our study, the students' perceptions of the service learning project as a powerful tool helps to shape students' satisfaction with the experience and to increase reinforcement of the material.

\section{Conclusion}

The results of this study strengthen the outcomes of previous studies in which communityengaged learning was found to reinforce classroom material and to provide students with valuable hands-on life experiences in the community. This study further adds to the growing body of research on community-engaged learning because it provides insight into pre-professional disciplines interwoven into online classes in a traditional university setting, particularly highlighting the power of community-engagement to develop professional identity and acumen in students as they make their transition into the workforce. The results of the study are consistent with the findings of previous studies that community-engaged learning is both enlightening and educationally satisfying. It also provides a helpful blueprint for other online instructors interested in incorporating community engagement into their classrooms. As research in this area continues to grow, whatever challenges arise in the context of community-engaged learning and preprofessional courses should be outweighed by the untapped potential of community-engaged learning as a powerful tool in higher education. 
Putting Theory Into Practice: Incorporating a Community Engagement Model Into Online

Pre-Professional Courses in Legal Studies and Human Resources Management

\section{References}

Barker, D. (2004). The scholarship of engagement: A taxonomy of five emerging practices. Journal of Higher Education Outreach and Engagement, 9(2), 123-137.

Behar-Horenstein, L. S., Isaac, N., Southwell, C. N., Hudson-Vassell, M. E., Niu, L., Pratto, M., ... Zafar, M. A. (2016). Promoting academic socialization through service learning experiences. International Journal of Teaching and Learning in Higher Education, 28(2), 158-67. Retrieved from http://www.isetl.org/ijtlhe

Bernier, A., \& Stenstrom, C. (2016). Moving from chance and "chemistry" to skills: Improving online student learning outcomes in small group collaboration. Education for Information, 32, 55-69.

Bossaller, J. S. (2016). Service learning as innovative pedagogy in online learning. Education for Information, 32, 35-53.

Bourelle, T. (2014). Adapting service-learning into the online technical communication classroom: A framework and model. Technical Communication Quarterly, 23, 247-264.

Boyatzis, R. E. (1998). Transforming qualitative data: Thematic analysis and code development. Thousand Oaks, CA: Sage.

Brail, S. (2013). Experiencing the city: Urban studies students and service learning. Journal of Geography in Higher Education, 37(2), 241-256.

Brail, S. (2016). Quantifying the value of service-learning: A comparison of grade achievement between service-learning and non-service-learning students. International Journal of Teaching and Learning in Higher Education, 28(2), 148-157.

Bringle, R. G., Hatcher J. G., \& Jones, S. G. (2011). International service learning: Conceptual frameworks and research. Michigan Journal of Community Service Learning, 17(2). Retrieved from https://quod.lib.umich.edu/m/mjcsl/3239521.0017.207/1

Brown, R. E. (2001, September). The process of community-building in distance learning classes. Journal of Asynchronous Learning Networks, 5(2). Retrieved from http://citeseerx.ist.psu.edu/viewdoc/download;jsessionid=72592EF8402CAA1FE75 58C38E303F509?doi=10.1.1.467.113\&rep=rep1\&type $=$ pdf

Butchey, D. (2014). Tools to make online students and community partners in a service learning project more "AT-EASE" - evidence from a finance class. Metropolitan Universities, 25(1), 125-146.

Carnegie Foundation for the Advancement of Teaching. (2008). Carnegie selects colleges and universities for new elective community engagement classification. Retrieved from http://www.carnegiefoundation.org/newsroom/news-releases/carnegie-selects-collegesuniversities-2015-community-engagement-classification/

Chickering, A. W., \& Reisser, L. (1993). Education and identity (2nd ed.). San Francisco, CA: Jossey-Bass Inc.

Cooks, L., \& Scharrer, E. (2006, Fall). Assessing learning in community service learning: A social approach. Michigan Journal of Community Service Learning, 44-55. Retrieved from http://files.eric.ed.gov/fulltext/EJ843846.pdf 
Dailey-Hebert, A., \& Donnelli, E. (2010). Service e-learning: Educating today's learners for an unscripted future. International Journal of Organizational Analysis, 12, 216-227.

Feen-Calligan, H., \& Matthews, W. K. (2016). Pre-professional arts based service-learning in music education and art therapy. International Journal of Education \& the Arts, 17(17). Retrieved from http://www.ijea.org/v17n17/

Felton, P., \& Clayton, P. H. (2011). Service learning. New Directions for Teaching and Learning, 128, 75-84.

Furze, J., Black, L., Peck, K., \& Jensen, G. M. (2011, August). Student perceptions of a community engagement experience. Physiotherapy Theory and Practice, 27(6), 411-421.

Helms, M. M., Rutti, R. M., Hervani, A. A., LaBonte, J., \& Sarkarat, S. (2015). Implementing and evaluating online service learning projects. Journal of Education for Business, 90, 369-378.

Hervani, A. A., Helms, M. M., Rutti, R. M., LaBonte, J., \& Sarkarat, S. (2015, Spring). Service learning projects in online courses: Delivery strategies. Journal of Learning in Higher Education, 11(1), 35-41.

Hoppes, H., Bender, D., \& DeGrace, B. W. (2003, Spring). Service learning is a perfect fit for occupational and physical therapy education. Journal of Allied Health, 34(1), 47-50.

Jackson, D. (2016a). Re-conceptualising graduate employability: The importance of preprofessional identity. Higher Education Research \& Development, 35(5), 925-939.

Jackson, D. (2016b). Developing pre-professional identity in undergraduates through workintegrated learning. The International Journal of Higher Education Research, 1-21.

Jenkins, A., \& Sheehey, P. (2012). A checklist for implementing service-learning in higher education. Journal of Community Engagement and Scholarship. Retrieved September 22, 2017 from http://jces.ua.edu/a-checklist-for-implementing-service-learning-in-highereducation/

Kelly, S. P., \& Miller, E. W. (2008). Education for service: Development of a service learning course. Journal of Physical Therapy Education, 22, 33-42.

Kuh, G. D., Kinzie, J., Buckley, J. A., Bridges, B. K., \& Hayek, J. C. (2007). Piecing together the student success puzzle: Research, propositions, and recommendations. ASHE Higher Education Report (Vol. 32, No. 5). San Francisco, CA: Jossey-Bass.

Lehman, R., \& Conceicao, S. (2010). Creating a sense of presence in online teaching: How to "be there" for distance learners. San Francisco, CA: John Wiley \& Sons.

Lincoln, Y. S., \& Guba, E. G. (1985). Naturalistic inquiry. Thousand Oaks, CA: Sage.

Lysne, S., Miller, B., \& Bradley, K. (2013). Exploring student engagement in an introductory biology course. Journal of College Science Teaching, 43(2), 14-19.

Marshall, C., \& Rossman, G. B. (1995). Designing qualitative research. (2nd ed.). Thousand Oaks, CA: Sage.

McGorry, S. Y. (2012). No significant difference in service learning online. Journal of Asynchronous Learning Networks, 16(4), 45-54. 
McNall, M., Sturdevant Reed, C., Brown, R. E., \& Allen, A. (2009). Brokering communityuniversity engagement. Innovation in Higher Education, 33(5), 317-331.

McNiff, J., \& Aicher, T. J. (2017). Understanding the challenges and opportunities associated with online learning: A scaffolding theory approach. Sport Management Education Journal, 11, 13-23.

Miles, M. B., \& Huberman, A. M. (1994). Qualitative data analysis: An expanded sourcebook. Thousand Oaks, CA: Sage.

Moore, C., Boyd, B. L., \& Dooley, K. E. (2010). The effects of experiential learning with an emphasis on reflective writing on deep-level processing of leadership students. Journal of Leadership Education, 9(1), 36-52.

Murray, L. I., Plante, J. D., Cox T. D., \& Owens, T. (2015, Fall). Service learning: Creating opportunities to expand students' worldviews. Journal of Learning in Higher Education, $11(2), 21-59$.

Nielson, D. (2016). Facilitating service learning in the online technical classroom. Journal of Technical Writing and Communication, 46(2), 236-256.

Patton, M. Q. (2002). Qualitative research and evaluation methods (3rd ed.). Thousand Oaks, CA: Sage.

Pelco, L. E., Ball, C. T., \& Lockerman, K. S. (2014). Student growth from service-learning: A comparison of first-generation and non-first-generation college students. Journal of Higher Education Outreach and Engagement, 18(2), 49-66.

Prentice, M., \& Robinson, G. (2010). Improving student learning outcomes with service learning. American Association of Community Colleges, 1-16.

Quaye, S. J., \& Harper, S. R. (2015). Student engagement in higher education: Theoretical perspectives and practical approaches for diverse populations (2nd ed.). New York, NY: Routledge.

Rovai, A. P. (2002, April). Building sense of community at a distance. The International Review of Research in Open and Distributed Learning, 3(1). Retrieved from http://www.irrodl.org/index.php/irrodl/article/view/79/153

Ruona, W. E. A. (2005). Analyzing qualitative data. In R. A. Swanson \& E. F. Holton, III (Eds.), Research in organizations: Foundations and methods of inquiry (pp. 233-263). San Francisco: Berrett-Koehler.

Sadera, W. A., Robertson, J., Song, L., \& Midon, M. N. (2009). The role of community in online learning success. MERLOT Journal of Online Learning and Teaching, 5(2). Retrieved from http://jolt.merlot.org/vol5no2/sadera_0609.pdf

Sapp, D. A., \& Crabtree, R. D. (2002). A laboratory in citizenship: Service learning in the technical communication classroom. Technical Communication Quarterly, 11(4), 411431.

Schindler, V. P. (2014). Community engagement: Outcomes for occupational therapy students, faculty, and clients. Occupational Therapy International, 21(2), 71-80. 
Seaman, J. E., Allen, I. E., \& Seaman, J. (2018). Grade increase: Tracking distance education in the United States. Babson Research Group. Retrieved from http://onlinelearningsurvey.com/reports/gradeincrease.pdf

Sheafer, V. (2014, December). Using service learning to teach classic learning theories. Psychology Journal, 11(2), 77-82.

Smith, S., Smith, C., Taylor-Smith, E., \& Fotheringham, J. (2017). In search of graduate employability: An exploration of student identity. Asia-Pacific Journal of Cooperative Education, 18(1), 15-24.

Song, L., Singleton, E. S., Hill, J. R., \& Koh, M. H. (2004). Improving online learning: Student perceptions of useful and challenging characteristics. Internet and Higher Education, 7(1), 59-70.

Stevenson, K. T., \& Peterson, M. N. (2015). How experiential service-learning affects student perceptions of education in their careers and as a wildlife management activity. Wildlife Society Bulletin, 39(4), 732-737.

Tesch, R. (1990). Qualitative research: Analysis types and software tools. London: Falmer.

van Es, R. (2003). Teaching business communication ethics with controversial films. Journal of Business Ethics, 17(16), 1817-1823.

Waldner, L. S., McGorry, S. Y., \& Widener, M. C. (2012). E-service-learning: The evolution of service-learning to engage a growing online student population. Journal of Higher Education Outreach and Engagement, 12(2), 123-150.

Zhao, J., \& Zhang, X. (2017). The influence of field teaching practice on pre-service teachers' professional identity: A mixed methods study. Frontiers in Psychology, 24(8). Retrieved from http://journal.frontiersin.org/article/10.3389/fpsyg.2017.01264/full 